centronuclear myopathy Duchenne muscular dystrophy erythrocytes myasthenia gravis polyamines

spermine

Werdig-Hoffman disease

\title{
Increased Erythrocytic Spermine in Duchenne Muscular Dystrophy
}

\author{
F. MOLlica, "1ti S. LI VOlTI, A. RAPISARDA, G. LONGO, L. PAVONE, AND A. VANELLA \\ Departments of Pediatrics [F. M., S. L. V., A. R., G. L., L. P., A. V.], Biochemistry [A. R., G. L.], and Animal \\ Biology /G. L.J, University of Catania, Catania, Italy
}

\section{Summary}

Erythrocytes of patients with Duchenne muscular dystrophy have been found to have elevated levels of spermine, a polyamine with a membrane-stabilizing action. Although a specific, increased spermine concentration is an additional biochemical abnormality documenting the involvement of erythrocyte membrane in Duchenne muscular dystrophy.

Normal level of spermine were found in female carriers.

\section{Speculation}

The generalized cell membrane involvement in Duchenne muscular dystrophy and in other myopathies may be inferred by an increased cellular concentration of substances, such as the polyamine spermine, which are involved in the maintenance of cellular stability.

Unfortunately, this characteristic of cells from myopathic patients is not utilizable for diagnostic purpose because it is not specific for a single myopathy, and it is not shared by the cells of healthy carriers.

The inborn error in Duchenne muscular dystrophy (DMD) is unknown, but different lines of evidence point to a systemic membrane defect as the primary lesion $(5,8,9,12,14)$. The recent demonstration that the first morphologic reaction leading to necrosis of the muscle fibers is disappearance of the plasma membrane (1) fits well with this hypothesis. In patients affected by DMD or by some other muscular dystrophies, we studied some

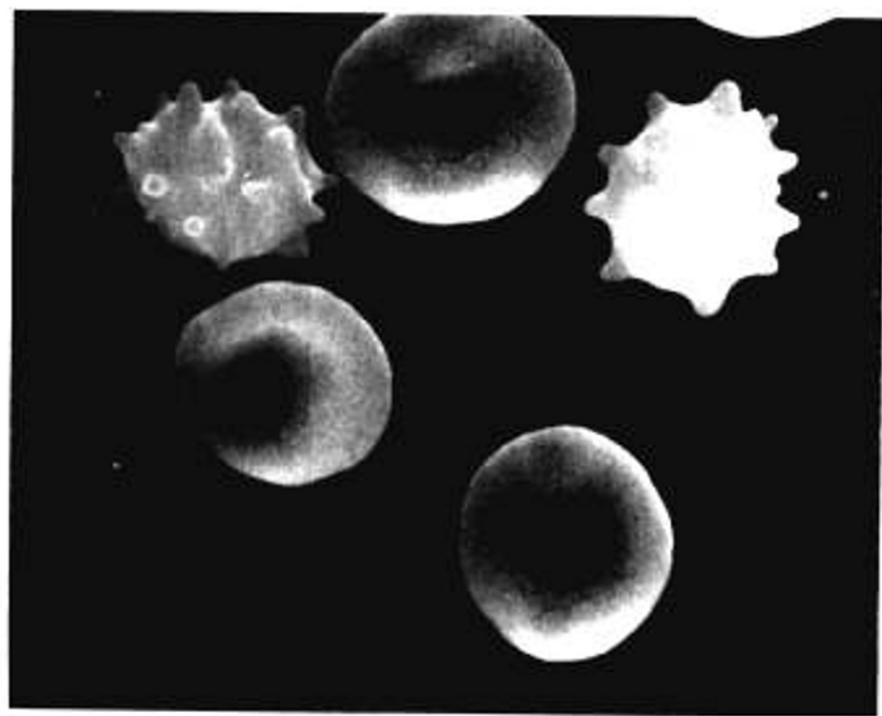

Fig. 1. Erythrocytes from patient with DMD. Scanning electron microscope JSM 35 A. morphologic, biophysical, and biochemical characteristics indicative of erythrocyte membrane involvement. The panel of tests included determination of the polyamines spermine and spermidine, which have a stabilizing action on cell membrane (11) and which to our knowledge have never been studied in erythrocytes of myopathic subjects. Among the anomalies encountered, increased spermine concentration in erythrocytes was the most consistent finding, but it was also present in myopathies other than DMD.

\section{MATERIALS AND METHODS}

The following subjects were studied: (1) seven patients affected by DMD (included a pair of monozygotic twins), with a mean age of 12.4 years, in whom the diagnosis was made by clinical examination, electromyography, and serum creatine phosphokinase determination. Their six mothers were also studied. Eight unaffected fathers and brothers served as controls. (2) two infants affected by Werdnig-Hoffman disease (WH), a girl affected by myasthenia gravis, and another affected by centronuclear myopathy (CNM). The four pairs of parents were also studied.

Table 1. Values of autohemolysis and erythrocytic spermidine and spermine in seven DMD patients and in their family members

\begin{tabular}{|c|c|c|c|}
\hline DMD & $\begin{array}{c}\text { Autohemolysis } \\
(\%)\end{array}$ & $\begin{array}{c}\text { Spermidine } \\
\text { (nmoles } / 10^{9} \mathrm{RBC} \text { ) }\end{array}$ & $\begin{array}{c}\text { Spermine } \\
\text { (nmoles } / 10^{y} \text { RBC) }\end{array}$ \\
\hline Patient a & 1.20 & 0.80 & 1.60 \\
\hline Patient b & 0.70 & 0.60 & 1.90 \\
\hline Father & 1.30 & 0.60 & 0.90 \\
\hline Mother & 1.10 & 0.40 & 0.90 \\
\hline Patient c & 0.90 & 1.00 & 2.10 \\
\hline Father & 1.30 & 0.60 & 0.90 \\
\hline Mother & 1.60 & 1.00 & 1.10 \\
\hline Brother & 1.10 & 0.80 & 0.90 \\
\hline Brother & 0.90 & 0.60 & 1.10 \\
\hline Patient d & 1.20 & 0.60 & 1.60 \\
\hline Father & 0.90 & 0.40 & 1.00 \\
\hline Mother & 0.90 & 0.40 & 1.20 \\
\hline Brother & 1.60 & 0.60 & 1.00 \\
\hline Patient e & 1.80 & 1.00 & 3.40 \\
\hline Father & 1.00 & 0.80 & 0.70 \\
\hline Mother & 0.70 & 0.80 & 1.10 \\
\hline Patient $\mathrm{f}$ & 1.40 & 0.60 & 1.60 \\
\hline Father & 1.00 & & \\
\hline Mother & 0.80 & 0.40 & 0.80 \\
\hline Patient $\mathrm{g}$ & 0.90 & 1.20 & 1.90 \\
\hline Father & 1.20 & 0.80 & 1.00 \\
\hline Mother & 0.80 & 0.80 & 1.20 \\
\hline
\end{tabular}


The investigations were: (1) a blind study of erythrocyte morphology by light microscope on routine peripheral blood smears and by scanning electron microscope according to the method of Matheson and Howland (3); (2) a study of osmotic fragility and of autohemolysis according to the method of Parpart et al. (4) and of Selwyn and Dacie (10); (3) determination of spermine and spermidine in erythrocyte preparations from venous blood samples by the method of Raina and Cohen $(6,7)$.

\section{RESULTS}

Only two of eleven patients (one with DMD and one affected by $\mathrm{WH}$ ) and one of the six mothers of DMD patients had over $50 \%$ of echinocytes at light and scanning microscope examination (Fig. 1). The other patients, the DMD mothers, and the controls had less than $20 \%$ of echinocytes and could not be distinguished from one another by the blinded examiner.

Normal values (from 4.4 to $3.2 \% \mathrm{NaCl}$ ) of osmotic fragility were found both in the myopathic subjects and in the controls.

The values of autohemolysis and erythrocytic spermidine and spermine in the patients and their relatives are reported in the Table 1 and 2. Autohemolysis was always in the normal range

Table 2. Values of autohemolysis and erythrocytic spermidine and spermine in four patients with different forms of myopathies and in their parents

\begin{tabular}{lccc}
\multicolumn{3}{c}{ their parents } \\
\hline & Autohemolysis & $\begin{array}{c}\text { Spermidine } \\
\text { (nmoles/10 }\end{array}$ & $\begin{array}{c}\text { Spermine } \\
\text { (nmoles } / 10^{9} \text { RBC) }\end{array}$ \\
\hline WH & & & \\
Patient a & 1.00 & 0.80 & 0.90 \\
Father & 0.60 & 1.00 & 0.80 \\
Mother & 0.50 & 0.60 & 0.70 \\
Patient b & 1.10 & 1.20 & 2.10 \\
Father & 0.70 & 0.60 & 1.20 \\
Mother & 0.90 & 0.60 & 2.00 \\
& & & \\
CNM & & 1.00 & 1.70 \\
Patient & 1.10 & 0.40 & 1.10 \\
Father & 0.90 & 0.60 & 0.70 \\
Mother & 1.50 & & \\
& & & \\
MG & & 0.60 & 1.00 \\
Patient & 1.05 & 0.40 & 0.80 \\
Father & 0.60 & 0.60 & 0.70 \\
Mother & 0.90 & & \\
\hline
\end{tabular}

( 0.5 to $2 \%)$. No significant differences were present in the spermidine levels between the patients and the controls.

DMD patients had levels of erythrocytic spermidine not significantly different from those of their unaffected relatives. On the other hand, the levels of erythrocytic spermine were significantly higher in the DMD patients than in their mothers and in unaffected males of their families $(P<0.01$ by the Student $t$ test $)$ (Fig. 2).

No correlation was found between spermine level and age or serum creatine phosphokinase activity. Erythrocytic spermine content was normal in all the six DMD mothers, four of whom had increased creatine phosphokinase levels (Fig. 2).

Spermine level in the range of DMD patients was obtained in one of two WH infants $\left[2.1\right.$ nmoles $/ 10^{9}$ red blood cells (RBC)] and in the patient affected by CNM $\left(1.7\right.$ nmoles $/ 10^{9}$ RBC) whereas the other two patients (one $\mathrm{WH}$ and one myastemia gravis) gave values in the control range $\left(0.9\right.$ and $1.0 \mathrm{nmoles} / 10^{9}$ $\mathrm{RBC}$, respectively).

\section{DISCUSSION}

Many studies performed in recent years in patients affected by DMD and by other myopathies have shown several morphological, biophysical, and biochemical abnormalities not only of the muscle fiber, but also of other cells (fibroblasts, leukocytes, and erythrocytes), giving direct support to a generalized cell membrane defect in these disorders $(5,8,9,12,14)$. Although the hypothesis of a generalized cell membrane involvement in DMD remains to be proven further, our demonstration of a consistently increased concentration of spermine in erythrocytes from myopathic patients gives additional evidence in this sense. It also suggests that the membrane defect is not confined to DMD but shared by other myopathies such as WH and CNM.

Marked elevation of putrescine and spermidine without apparent change in spermine concentration have been recently found in muscle biopsy specimens of DMD patients (2). It has been suggested that polyamines play an important role as cellular antioxidants and membrane stabilizers (13). Therefore, the high levels of polyamines found in the myopathic subjects could have the significance of a compensatory phenomenon in an effort to protect the cellular membrane from its involvement.

According to our results among the parameters that we have studied, increased spermine concentration in erythrocytes is the most consistent abnormal finding. Nevertheless, it unfortunately cannot be utilized for diagnostic purpose because it is not specific for a given myopathy and it is not found in the female carriers of DMD.
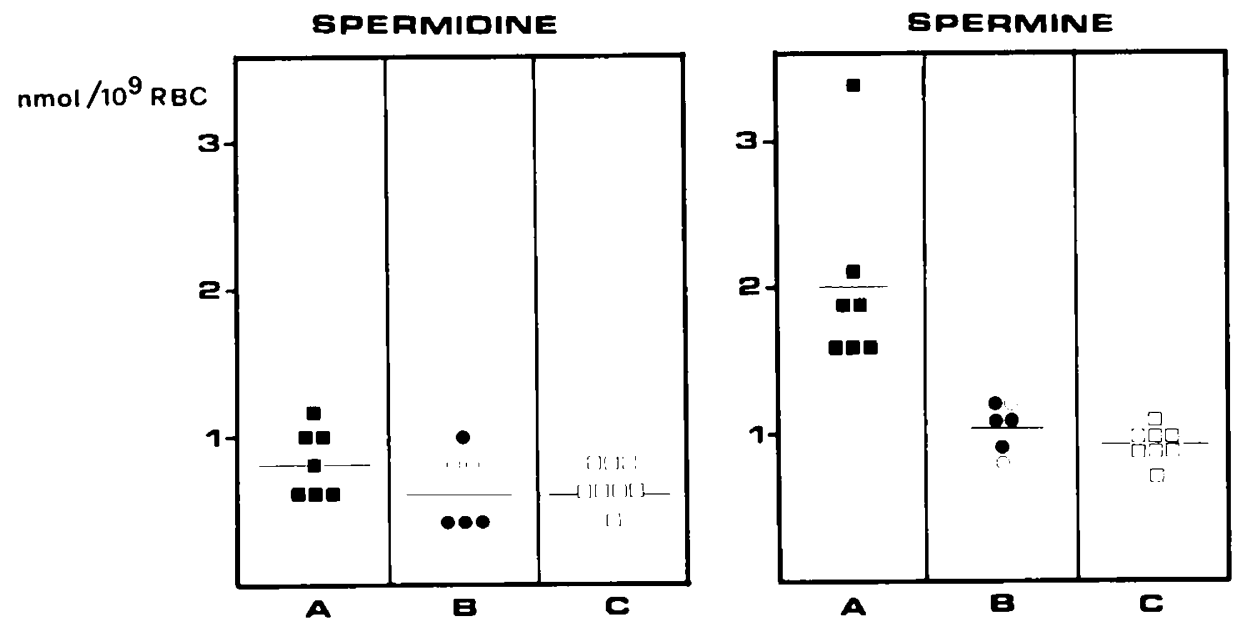

Fig. 2. Erythrocytic spermidine and spermine in seven DMD patients $(A)$, in their six mothers $(B)$, and in eight unaffected males of their families $(C) . \square$, subjects with increased serum creatine phosphokinase; $O, \square$, subjects with normal serum creatine phosphokinase. 


\section{REFERENCES AND NOTES}

I. Carpenter, S., and Karpati, G.: Duchenne muscular dystrophy. Plasma membrane loss initiates muscle cell necrosis unless it is repaired. Brain, 102: 147 (1979).

2. Kremzner, L. T., Tennyson, V. M., and Miranda. A. F.: Polyamine metabolism in normal denervated, and dystrophic muscle. In: R. A. Campbell, D. R. Morris, D. Bartos, G. D. Daves, F. Bartos: Advances in Polyamine Research. Vol. 2, pp. 241-255 (Raven Press, New York, 1978).

3. Matheson, D. W.. and Howland, J. L.: Erythrocyte deformation in human muscular dystrophy. Science (Wash. D. C.), 184: 165 (1974)

4. Parpart, A. K., Lorenz, P. B., Parpart, E. R., Gregg. J. R., and Chase, A. M.: The osmotic resistance (fragility) of human red cells. J. Clin. Invest., 26: 636 (1947).

5. Pickard, N. A., Gruemer, H. D., Verrill, H. L., Isaacs, E. R., Robinow. M., Nance, W. E., Myers, E. C., and Goldsmith, B.: Systemic membrane defect in the proximal muscular dystrophies. N. Engl. J. Med.. 299: 841 (1978).

6. Raina, A.: Spermine and spermidine in normal human blood. Scand. J. Clin. Lab. Invest., 14: 318 (1962).

7. Raina. A.. and Cohen, S.: Polyamines and RNA synthesis in a polyauxotrophic strain of E. Coli. Proc. Natl. Acad. Sci. U. S. A., 55: 1587 (1966)

8. Roland, L. P.: Pathogenesis of muscular dystrophies. Arch. Neurol., 33: 315 (1976).

9. Schotland. D. L., Bonilla, E., and Van Meter, M.: Duchenne dystrophy: alteration in muscle plasma membrane structure. Science (Wash. D. C.), 196: 1005 (1977).

10. Seiwyn, J. G., and Dacie, J. V.: Autohemolysis and other changes resulting from the incubation in vitro of red cells from patients with congenital hemolytic anemia. Blood, 9: 414 (1954).

11. Tabor, H.. and Tabor, C.: Spermidine, spermine and related amines. Pharmacol Rev., 16: 245 (1964)

12. Tillmann, W., Lenard, H. G., Wagner, D., Donges, H., and Schroter, W Rheologic properties of erythrocytes in Duchenne muscular dystrophy. Pediat Res.. 13: 152 (1979).

13. Vanella, A., Rizza, V., Rapisarda, A., and Pinturo, R.: Inhibitor effect of polyamines on reduction of cytochrome $c$ by superoxide $\mathrm{O}_{2}$. Ital. J. Biochem. 28: 387 (1979)

14. Wakayama. Y., Hodson. A., Pleasure. D., Bonilla, E., and Schotland, D. L. Alteration in erythrocyte membrane structure in Duchenne muscular dystrophy. Ann. Neurol., 4: 253 (1978).

15. Appropriate informed consent was obtained for this study.

16. Requests for reprints should be addressed to: Prof. Florindo Mollica, Policlinico Universitario. Clinica Pediatrica dell'Università. Viale A. Doria 6, Catania. Italy.

17. Received for publication December 5. 1979

18. Accepted for publication April 22, 1980. 